\title{
IMPLEMENTASI METODE SAW DALAM MENENTUKAN MEDIA PROMOSI (STUDI KASUS PADA LPP LPS KOMPUTER AIR JOMAN)
}

\author{
Elly Rahayu ${ }^{1}{ }^{*}$, Masitah Handayani ${ }^{1}$, Rohminatin ${ }^{1}$ \\ Program Studi Sistem Informasi, STMIK Royal, Kisaran \\ "email: ellyrahayu68@gmail.com
}

\begin{abstract}
Abstrak: Lembaga Pendidikan dan Pelatihan LPS Komputer Air Joman berdiri sejak tahun 2010 dibawah naungan Dinas Pendidikan Kabupaten Asahan. Ditinjau dari sisi letaknya yang berada diantara Kota Kisaran dengan Kota Masya Tanjung Balai maka LPP LPS Komputer Air Joman harus bekerja lebih keras untuk dapat menarik minat konsumen untuk belajar di lembaga tersebut. Untuk itu perlu pemilihan media promosi yang tepat. Rumusan masalah pada penelitian ini adalah bagaimana mengimplementasikan metode SAW dalam menentukan media promosi terbaik bagi LPP LPS Komputer Air Joman. Tujuannya adalah mengimplementasikan media SAW dalam menentukan media promosi yang tepat bagi LPP LPS Komputer Air Joman. Pemilihan media promosi dilakukan dengan metode Simple Additive Weithing (SAW). Langkah-langkah yang dilakukan adalah: menentukan nilai kriteria masing-masing alternativ, menentukan bobot , melakukan normalisasi matrik dan melakukan proses normalisasi matriks keputusan ke skala yang dibandingkan dengan semua rating alternative. Hasil Penelitiannya adalah bauran promosi dengan alternative Promosi Penjualan sebagai media yang terbaik dengan nilai 1,75.
\end{abstract}

Kata Kunci : Metode SAW, Promosi, Media Promosi, Lembaga Pendidikan dan Pelatihan, LPS

\begin{abstract}
Education and Training Institute LPS Computer Air Joman established since 2010 under the auspices of the Asahan District Educational Office. It is Located between Kisaran City and Kota Madya Tanjung Balai then LPP LPS Computer Air Joman must work harder to be able to attract consumers to study at the institution. For that we need the right promotion media to be informs that institusion. The formulation problem in this research is how to implement SAW method in determining the best promotion media for LPP LPS Computer Air Joman. The goal is to implement SAW media in determining the right media promotion for LPP LPS Computer Air Joman. The selection of promotion media is done by Simple Additive Weithing (SAW) method. The steps taken are: determine the criteria value of each alternative, determine the weight, normalize the matrix and perform the process of normalizing the decision matrix to the scale compared with all the alternative rating. The result of the research is promotion mix with Sales Promotion alternative as the best media with value 1.75 .
\end{abstract}

Keywords: SAW Method, Promotion, Media Promotion, Institute of Education and Training, LPS 
DOI: https://doi.org/10.33330/jurteksi.v5i2.353

Available online at http://jurnal.stmikroyal.ac.id/index.php/jurteksi

\section{PENDAHULUAN}

Lembaga Pendidikan dan Pelatihan (LPP) LPS Komputer Air Joman yang terletak di jalan Syech Silau Desa Punggulan Kecamatan Air Joman Kabupaten berdiri sejak tahun 2010 yang berada dibawah naungan Dinas Pendidikan Kabupaten Asahan. Lembaga ini menjadi salah satu alternative bagi masyarakat sekitarnya untuk meningkatkan kemampuan dibidang Komputer. Jasa pendidikan yang ditawarkan oleh Lembaga Pendidikan dan Pelatihan LPS Komputer Air Joman adalah pendidikan komputer tingkat sekolah dasar sampai dengan tingkatan SMU. Disamping itu juga menyediakan pendidikan komputer untuk umum.

Air Joman merupakan kecamatan dengan luas wilayah $92.86(\mathrm{~km} 2)$, sebelah utara berbatasan dengan Silau Laut, sebelah Selatan dengan Sei Dadap, sebelah Timur dengan Kota Tanjung Balai dan Barat dengan Kisaran Timur dengan jumlah penduduk pada tahun 2016 adalah sebesar 48.856 [1], Terdapat 48 sekolah dari tingkatan SD sampai SMU dengan jumlah siswa sebesar 9.460 orang pada tahun 2016. Ini merupakan pasar potensial bagi LPP LPS Komputer Air Joman, sementara jumlah sekolah dari mulai Sekolah Dasar (SD) sampai dengan Sekolah Menengah Umum dapat dilihat pada tabel 1 .

Promosi memegang peranan penting dalam Manajemen Pemasaran. Hal ini sejalan dengan pendapat yang menyatakan bahwa promosi adalah sarana dimana perusahaan berusaha untuk mengin-formasikan, membujuk dan mengingatkan konsumen baik secara langsung atau tidak langsung tentang produk dan merek yang mereka jual [2]. Promosi adalah salah satu unsur dalam bauran pemasaran perusa-haan yang didayagunakan untuk memberitahukan, membujuk, dan mengingatkan tentang produk perusa-haan, dengan harapan mempengaruhi penerima, sehingga merasa percaya [3]. Hasil penelitian menyatakan bahwa promosi secara simultan dan parsial berpengaruh terhadap pening-katan jumlah siswa yang belajar komputer pada Lembaga Pendidikan dan Pelatihan LPS Komputer Air Joman [4].

Menurut Dari definisi diatas dapat disimpulkan bahwa promosi merupakan variable pemasaran yang harus dilakukan oleh perusahaan untuk menginformasikan produk atau jasanya serta membujuk konsumen untuk melakukan pembelian.

Tabel 1. Jumlah Sekolah di Kec. Air Joman Tahun 2016

\begin{tabular}{clcc}
\hline NO & Tingkatan Sekolah & Jumlah & $\begin{array}{c}\text { Jumlah } \\
\text { Siswa }\end{array}$ \\
\hline $\mathbf{1}$ & $\begin{array}{l}\text { SD \& Madrasah } \\
\text { Ibtidaiyah (MI) }\end{array}$ & 30 & 5.140 \\
\hline $\mathbf{2}$ & $\begin{array}{l}\text { SMP \& Madrasah } \\
\text { Tsanawiyah (MTs) }\end{array}$ & 12 & 2.838 \\
\hline $\mathbf{3}$ & $\begin{array}{l}\text { SMU \& Madrasah } \\
\text { Aliyah (MA) }\end{array}$ & 6 & 1.482 \\
\hline \multicolumn{3}{lc}{ Total } & 48 \\
\hline Sumber: Asahan Dalam Angka, 2017
\end{tabular}

Bila ditinjau dari letak Kecamatan Air Joman diantara Kota Kisaran dengan Kotamadya Tanjung Balai serta segmen pasar yang cukup potensial, tentunya menjadi tantangan besar bagi LPP LPS Komputer Air Joman untuk terus meningkatkan jumlah siswa yang belajar komputer di lembaganya. Jika tidak tepat dalam memilih media promosi, maka informasi tentang lembaga tersebut tidak 
akan sampai ke konsumen dan dampak negatifnya adalah konsumen akan memilih lembaga kursus lain yang ada di Kota Kisaran dan Tanjung Balai. Oleh karenanya perlu memilih media promosi yang tepat untuk dapat menginformasikan, mengenalkan serta membujuk konsumen untuk memilih LPP LPS Komputer Air Joman sebagai lembaga kursus Komputer. Pada penelitian ini pemilihan media promosi dilakukan dengan metode Simple Additive Weighting (SAW).

Berdasarkan latar belakang tersebut diatas maka dapat dirumuskan permasalahan pada penelitian ini adalah bagaimana mengimplementasikan metode SAW dalam pemilihan media promosi yang tepat bagi LPP LPS Komputer Air Joman?. Tujuan penelitian ini adalah menginplementasikan metode SAW dalam pemilihan media promosi yang tepat bagi LPP LPS Komputer Air Joman.

\section{METODE}

Metode SAW sering dikenal dengan istilah metode penjumlahan terbobot. Konsep dasar metode SAW adalah mencari penjumlahan terbobot dari rating kinerja pada setiap alternatif pada semua atribut. Metode SAW dapat membantu dalam pengambilan keputusan suatu kasus, akan tetapi perhitungan dengan menggunakan metode SAW ini hanya yang menghasilkan nilai terbesar yang akan terpilih sebagai alternatif yang terbaik. [5].

Metode SAW membutuhkan proses normalisasi matriks keputusan (X) ke suatu skala yang dapat diper-bandingkan dengan semua rating alternatif yang ada.

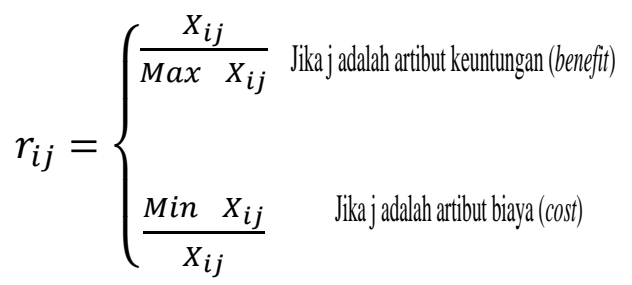

Di mana:

$X \_i j=$ nilai atribut yang dimiliki setiap kriteria

Max X_ij= nilai terbesar dari setiap kriteria

Min $X_{-} i j=$ nilai terkecil dari setiap kriteria

Benefi $=$ jika nilai tebesar adalah terbaik Cost $=$ jika nilai terkecil adalah terbaik r_ij adalah rating kerja ternormalisasi dari alternatif $\mathrm{A}_{-} \mathrm{i}$ pada atribut $\mathrm{C}_{-} \mathrm{j}$; $\mathrm{i}=1,2, \ldots, \mathrm{m}$

dan $\mathrm{j}=1,2, \ldots, n$. Nilai preferensi untuk setiap alternatif (V_i) diberikan sebagai :

$$
V i=\sum_{j=1}^{n} w_{j} r_{i j}
$$

Di mana:

$V i \quad=$ ranking untuk setiap alternatif

$w_{j} \quad=$ nilai bobot dari setiap kriteria

$r_{i j}=$ nilai rating kinerja ternormalisasi

Nilai $V i$ yang lebih besar mengindikasikan bahwa alternatif $A i$ lebih terpilih.

Keterangan :

$A$ : Alternatif

$C$ : Kriteria

$W$ : Bobot Preferensi

$V \quad$ : Nilai preferensi untuk setiap alternatif

$X$ : Nilai Alternatif dari setiap kriteria (Verina Valensia et al, 2012) [6]. Langkah penyelesaian metode FMADM dengan metode SAW antara lain :

Memberikan nilai setiap alternatif (Ai) 
pada setiap kriteria $(\mathrm{Cj})$ yang sudah ditentukan, dimana nilai tersebut diperoleh berdasarkan nilai crisp; $\mathrm{i}=1,2, \ldots, \mathrm{m}$ dan $\mathrm{j}=1,2, \ldots, \mathrm{n}$, dimana nilai crisp adalah sebuah himpunan tegas, nilai anggota suatu item dalam suatu himpunan A memiliki dua kemungkinan yaitu 0 artinya suatu item tidak menjadi anggota dalam himpunan tersebut dan 1 yang artinya suatu item menjadi anggota himpunan tersebut.

a. Memberikan nilai bobot (W) yang juga didapatkan berdasarkan nilai crisp.

b. Melakukan normalisasi matriks dengan cara menghitung nilai rating kinerja ternormalisasi (rij) dari alternatif $\mathrm{Ai}$ pada atribut $\mathrm{Cj}$ berdasarkan persamaan yang disesuaikan dengan jenis atribut (atribut keuntungan/benefit = MAKSIMUM atau atribut biaya/cost $=$ MINIMUM). Apabila berupa atribut keuntungan maka nilai crisp (Xij) dari setiap kolom atribut dibagi dengan nilai crisp MAX (MAX Xij) dari tiap kolom, sedangkan untuk atribut biaya, nilai crisp MIN (MIN Xij) dari tiap kolom atribut dibagi dengan nilai crisp (Xij) setiap kolom.

c. Melakukan proses perankingan dengan cara mengalikan matriks ternormalisasi $(\mathrm{R})$ dengan nilai bobot (W).

d. Menentukan nilai preferensi untuk setiap alternatif (Vi) dengan cara menjumlahkan hasil kali antara matriks ternormalisasi (R) dengan nilai bobot $(\mathrm{W})$. Nilai Vi yang lebih besar mengindikasikan bahwa alternatif Ai lebih terpilih [7].

\section{HASIL DAN PEMBAHASAN}

Penelitian ini dilaksanakan menggunakan data-data yang telah didapatkan dari LPP LPS Komputer Air Joman . Data-data tersebut akan dijadikan sebagai nilai dasar untuk perbandingan alternatif dan kriteria. Setelah melakukan penilaian pada masing-masing kriteria, seluruh data diproses dengan menggunakan metode Simple Additive Weighting. Output yang dihasilkan berupa ranking media promosi pada LPP LPS Komputer Air Joman.

Alur proses yang dilalui dalam memilih media promosi dilakukan dengan menggunakan metode Simple Additive Weighting dimulai dari penentuan alternatif dan kriteria, dimana alternatif dari media promosi adalah periklanan, promosi penjualan, penjualan personal, hubungan masyarakat dan penjualan langsung. Sedangkan kriteria tersebut terdiri segmen pasar, waktu, skala promosi dan biaya. Proses selanjutnya adalah menentukan nilai kecocokan Fuzzy dari tiap kriteria, setelah itu akan diproses sehingga diperoleh nilai normalisasi pada masing-masing kriteria[8]. Setelah mendapatkan nilai normalisasi, maka langkah selanjutnya adalah menghitung nilai preferensi di mana nilai tersebut didapat dari perbandingan antara kriteria media promosi dengan maksimum nilai kriteria yang selanjutnya hasil preferensi dikalikan dengan weighted.

Weighted merupakan bobot kepentingan dari masing-masing kriteria. Dengan demikian didapatlah nilai total dengan menggunakan rumus sampai akhirnya perangkingan pemilihan media promosi yang direkomendasikan untuk LPP LPS Air Joman. Nilai Preferensi 
DOI: https://doi.org/10.33330/jurteksi.v5i2.353

Available online at http://jurnal.stmikroyal.ac.id/index.php/jurteksi

tertinggi merupakan alternatif terpilih[9].

\section{Analisa Kebutuhan Data Alternatif}

Ada lima alternatif yang digunakan di dalam pemilihan media promosi seperti yang terlihat pada tabel 2 .

Tabel 2. Alternatif Bauran Promosi NO ALTERNATIF MEDIA PROMOSI

\begin{tabular}{ll}
\hline $\mathbf{1}$ & Periklanan \\
\hline $\mathbf{2}$ & Promosi Penjualan \\
\hline $\mathbf{3}$ & Penjualan Personal \\
\hline $\mathbf{4}$ & Hubungan Masyarakat \\
$\mathbf{5}$ & Penjualan Langsung \\
\hline
\end{tabular}

\section{Analisa Kebutuhan Data Kriteria}

Ada empat kriteria yang digunakan di dalam pemilihan media promosi yaitu segmen pasar, waktu, skala promosi dan biaya dengan skor tertinggi adalah 5 yang terlihat pada table 3 .

Tabel 3. Rekapitulasi Angket Perhitungan Skor Kriteria Media Promosi

Proses survei yang dilakukan dengan menggunakan metode angket guna menentukan prioritas dari masingmasing kriteria. Hasil dari proses survei ini kemudian dicari nilai rata-ratanya.

Langkah-langkah perhitungan metode Simple Additive Weighting untuk pemilihan media promosi adalah sebagai berikut:

\section{Nilai Kriteria Pada Masing-Masing Alternatif}

Tabel 4. Nilai Kriteria pada MasingMasing Alternatif

\begin{tabular}{cccccc}
\hline No & Alternatif & \multicolumn{4}{c}{ Nilai Kriteria } \\
\cline { 3 - 6 } & & C1 & C2 & C3 & C4 \\
\hline $\mathbf{1}$ & A1 & 3,26 & 2,87 & 2,57 & 2,98 \\
\hline $\mathbf{2}$ & A2 & 4,00 & 2,92 & 3,41 & 3,12 \\
\hline $\mathbf{3}$ & A3 & 4,10 & 2,86 & 2,99 & 3,24 \\
\hline $\mathbf{4}$ & A4 & 2,65 & 2,28 & 3,63 & 2,60 \\
\hline $\mathbf{5}$ & A5 & 3,23 & 3,20 & 2,87 & 3,08 \\
\hline
\end{tabular}

Ada 4 kriteria yang akan dijadikan acuan dalam pemilihan media promosi yaitu: segmen pasar, waktu, skala promosi dan biaya. Di dalam setiap

\begin{tabular}{|c|c|c|c|c|c|}
\hline \multirow[t]{2}{*}{ No } & Nama & \multicolumn{3}{|c|}{ Skor Rata-Rata Kriteria } & 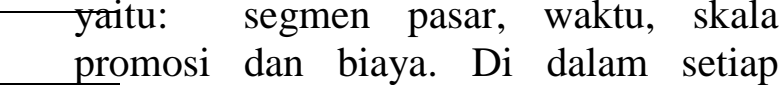 \\
\hline & $\begin{array}{c}\text { Media } \\
\text { Promosi }\end{array}$ & $\begin{array}{c}\text { Segmen } \\
\text { Pasar }\end{array}$ & Waktu & $\begin{array}{c}\text { Skala } \\
\text { Promosi }\end{array}$ & Biayariteria memiliki jangkauan nilai atau \\
\hline 1 & Periklanan & 3,26 & 2,87 & 2,57 & 2,98 dalam bilangan Fuzzy yang kemudian \\
\hline 2 & $\begin{array}{l}\text { Promosi } \\
\text { Penjualan }\end{array}$ & 4,00 & 2,92 & 3,41 & $\begin{array}{l}\text { 3,1 akan ditransformasikan di dalam bilangan } \\
\text { tersebut. Adapun nilai jangkauan atau }\end{array}$ \\
\hline 3 & $\begin{array}{l}\text { Penjualan } \\
\text { Personal }\end{array}$ & 4,10 & 2,86 & 2,99 & 3,2 bobotnya adalah sebagai berikut: \\
\hline 4 & $\begin{array}{l}\text { Hubungan } \\
\text { Masyarakat }\end{array}$ & 2,65 & 2,28 & 3,63 & Segmen Pasar \\
\hline 5 & $\begin{array}{l}\text { Penjualan } \\
\text { Langsung }\end{array}$ & 3,23 & 3,20 & 2,87 & $\begin{array}{l}\text { 3,08 Kriteria segmen pasar memiliki } \\
\text { lima jangkauan nilai seperti yang terdapat }\end{array}$ \\
\hline
\end{tabular}

Analisa Metode Simple Additive Weighting (SAW) Dalam Pemilihan Media promosi 
JURTEKSI (Jurnal Teknologi dan Sistem Informasi)

Vol. V No. 2, Juni 2019, hlm.105 - 112

DOI: https://doi.org/10.33330/jurteksi.v5i2.353

Available online at http://jurnal.stmikroyal.ac.id/index.php/jurteksi
ISSN 2407-1811 (Print)

ISSN 2550-0201 (Online)
Tabel 5. Nilai Kriteria Segmen Pasar dan Fuzzy

\begin{tabular}{clc}
\hline $\begin{array}{c}\text { Segmen Pasar } \\
\left(\mathbf{C}_{\mathbf{1}}\right)\end{array}$ & Keterangan & $\begin{array}{c}\text { Nilai } \\
\text { Fuzzy }\end{array}$ \\
\hline $\mathbf{0 , 0 0}-\mathbf{1}$ & Sangat Jauh(SJ) & 0 \\
\hline $\mathbf{1 , 0 1}-\mathbf{2 , 0 0}$ & Jauh $(\mathrm{J})$ & 0,25 \\
\hline $\mathbf{2 , 0 1}-\mathbf{3 , 0 0}$ & Cukup DekatCD) & 0,5 \\
\hline $\mathbf{3 , 0 1}-\mathbf{4 , 0 0}$ & Dekat (D) & 0,75 \\
\hline $\mathbf{4 , 0 1 - \mathbf { 5 , 0 0 }}$ & Sangat Dekat(SD) & 1 \\
\hline
\end{tabular}

b. Waktu

Kriteria waktu memiliki lima jangkauan nilai seperti yang terdapat pada tabel 6.

Tabel 6. Nilai Kriteria Waktu dan Fuzzy

\begin{tabular}{clc}
\hline $\begin{array}{c}\text { Waktu } \\
\left(\mathbf{C}_{\mathbf{2}}\right)\end{array}$ & \multicolumn{1}{c}{ Keterangan } & $\begin{array}{c}\text { Nilai } \\
\boldsymbol{F u z z y}\end{array}$ \\
\hline $\mathbf{0 , 0 0}-\mathbf{1}$ & Tidak Lama (TL) & 0 \\
\hline $\mathbf{1 , 0 1 - 2 , 0 0}$ & Kurang Lama (KL) & 0,25 \\
\hline $\mathbf{2 , 0 1 - 3 , 0 0}$ & Cukup Lama (KL) & 0,5 \\
\hline $\mathbf{3 , 0 1 - 4 , 0 0}$ & Lama (L) & 0,75 \\
\hline $\mathbf{4 , 0 1 - 5 , 0 0}$ & Sangat Lama (SL) & 1 \\
\hline
\end{tabular}

\section{c. Skala Promosi}

Kriteria skala promosi memiliki lima jangkauan nilai seperti yang terdapat pada tabel 7.

Tabel 7. Nilai Skala Promosi dan Fuzzy

\begin{tabular}{ccc}
\hline $\begin{array}{c}\text { Skala } \\
\text { Promosi } \\
\left(\mathbf{C}_{\mathbf{3}}\right)\end{array}$ & Keterangan & $\begin{array}{c}\text { Nilai } \\
\text { Fuzzy }\end{array}$ \\
\hline $\mathbf{0 , 0 0}-\mathbf{1}$ & Sangat Jarang (SJ) & 0 \\
\hline $\mathbf{1 , 0 1 - 2 , 0 0}$ & Jarang (J) & 0,25 \\
\hline $\mathbf{2 , 0 1 - 3 , 0 0}$ & Cukup Sering (CS) & 0,5 \\
\hline $\mathbf{3 , 0 1}-\mathbf{4 , 0 0}$ & Sering (S) & 0,75 \\
\hline $\mathbf{4 , 0 1 - \mathbf { 5 , 0 0 }}$ & Sangat Sering (SS) & 1 \\
\hline
\end{tabular}

d. Biaya

Kriteria biaya memiliki lima jangkauan nilai seperti yang terdapat pada tabel 8.

Tabel 8. Nilai Kriteria Biaya dan Fuzzy

\begin{tabular}{ccc}
\hline Biaya $\left(\mathbf{C}_{\mathbf{4}}\right)$ & Keterangan & Nilai $\boldsymbol{F u z z y}$ \\
\hline $\mathbf{0 , 0 0}-\mathbf{1}$ & Sangat Rendah $(\mathrm{SR})$ & 0 \\
\hline $\mathbf{1 , 0 1}-\mathbf{2 , 0 0}$ & Rendah $(\mathrm{R})$ & 0,25 \\
\hline $\mathbf{2 , 0 1}-\mathbf{3 , 0 0}$ & Cukup Tinggi (CT) & 0,5 \\
\hline $\mathbf{3 , 0 1}-\mathbf{4 , 0 0}$ & Tinggi (T) & 0,75 \\
\hline $\mathbf{4 , 0 1}-\mathbf{5 , 0 0}$ & Sangat Tinggi (ST) & 1 \\
\hline
\end{tabular}

\section{Bobot}

Dalam penelitian ini, nilai bobot kepentingan (weight) dan nilai bobot kriteria didapat dari standar yang dimiliki LPP LPS Komputer Air Joman dalam memilih media promosi. Adapun nilai bobot kepentingan pada masing-masing kriteria dapat dilihat pada tabel 9.

Tabel 9. Nilai Bobot Kepentingan (Weighted) pada Masing-Masing Kriteria

\begin{tabular}{lc}
\hline \multicolumn{1}{c}{ Kriteria } & $\begin{array}{c}\text { Nilai Bobot } \\
\text { Kepentingan } \\
(\text { Weighted })\end{array}$ \\
\hline Segmen Pasar $\left(\mathbf{C}_{1}\right)$ & 0,25 \\
\hline Waktu $\left(\mathbf{C}_{2}\right)$ & 0,50 \\
\hline Skala Promosi $\left(\mathbf{C}_{3}\right)$ & 1 \\
\hline Biaya $\left(\mathbf{C}_{4}\right)$ & 0,25 \\
\hline
\end{tabular}

\section{Normalisasi Matrik}

Berdasarkan data yang telah dihitung nilainya, maka selanjutnya data tersebut ditransformasikan ke dalam rating kecocokan bilangan Fuzzy dari setiap kriteria. Keterangan data transformasi dapat dijelaskan pada tabel 10 . 
DOI: https://doi.org/10.33330/jurteksi.v5i2.353

Available online at http://jurnal.stmikroyal.ac.id/index.php/jurteksi

Tabel 10. Kecocokan Terhadap Fuzzy

Dari Setiap Alternatif Pada Kriteria

\begin{tabular}{ccccc}
\hline Alternatif & \multicolumn{4}{c}{ Kriteria } \\
\cline { 2 - 5 } & C1 & C2 & C3 & C4 \\
\hline $\mathbf{A 1}$ & 0,75 & 0,50 & 0,75 & 0,50 \\
\hline $\mathbf{A 2}$ & 1 & 0,50 & 0,75 & 0,75 \\
\hline $\mathbf{A 3}$ & 0,50 & 0,50 & 0,50 & 0,75 \\
\hline $\mathbf{A 4}$ & 0,75 & 0,75 & 0,75 & 0,50 \\
\hline $\mathbf{A 5}$ & 0,75 & 0,75 & 0,75 & 0,75
\end{tabular}

Setelah membuat rating kecocokan kriteria dengan nilai yang didapat dari tabel di atas, selanjutnya nilai dikelompokkan dalam sebuah matriks, seperti berikut ini:

$$
X=\left(\begin{array}{cccc}
C 1 & C 2 & C 3 & C 4 \\
0,75 & 0,50 & 0,75 & 0,50 \\
1 & 0,50 & 0,75 & 0,75 \\
0,50 & 0,50 & 0,50 & 0,75 \\
0,75 & 0,75 & 0,75 & 0,50 \\
0,75 & 0,75 & 0,75 & 0,75
\end{array}\right)
$$

Proses Normalisasi Matriks Keputusan ke Skala yang Dibandingkan dengan Semua Rating Alternatif .

Pada metode Simple Additive Weighting (SAW), membutuhkan proses normalisasi matriks dengan cara menghitung nilai dari rating alternatif terhadap kriteria-kriteria berdasarkan nilai bobot yang sudah disesuaikan. Kriteria segmen pasar, waktu dan skala promosi adalah benefit, sedangkan kriteria biaya adalah cost.

\section{Proses Preferensi untuk Tiap Alternatif}

Menentukan nilai preferensi untuk setiap alternatif dengan cara menjumlahkan hasil kali antara matriks ternormalisasi dengan nilai bobot. Nilai V yang terbesar mengindikasikan bahwa media promosi tersebut memiliki tingkat terpilih paling tinggi untuk menjadi media promosi terbaik. Dan jika dilakukan perankingan akan terlihat seperti tabel 11.

Tabel 11 Hasil Perangkingan Metode SAW

\begin{tabular}{clc}
\hline No. & Nama Media Promosi & Nilai \\
\hline $\mathbf{1}$ & Promosi Penjualan & 1,75 \\
\hline $\mathbf{2}$ & Hubungan Masyarakat & 1,71 \\
\hline $\mathbf{3}$ & Penjualan Langsung & 1,53 \\
\hline $\mathbf{4}$ & Periklanan & 1,44 \\
$\mathbf{5}$ & Penjualan Personal & 1,42 \\
\hline \multicolumn{3}{c}{ Bauran Promosi dengan alternatif } \\
Promosi Penjualan terpilih menjadi media \\
promosi terbaik dengan nilai 1,75
\end{tabular}

\section{SIMPULAN}

Alur proses yang dilalui dalam memilih media promosi dilakukan dengan menggunakan metode Simple Additive Weighting dimulai dari penentuan alternatif dan kriteria, dimana alternatif dari media promosi adalah periklanan, promosi penjualan, penjualan personal, hubungan masyarakat dan penjualan langsung. Sedangkan kriteria tersebut terdiri segmen pasar waktu, skala promosi dan biaya. Hasil penelitiannya adalah Media Promosi dengan alternative Promosi Penjualan menjadi media yang 
DOI: https://doi.org/10.33330/jurteksi.v5i2.353

Available online at http://jurnal.stmikroyal.ac.id/index.php/jurteksi

terbaik untuk LPP LPS Komputer Air Joman.

\section{DAFTAR PUSTAKA}

[1] Badan Pusat Statistik, 2017. Asahan Dalam Angka 2017.

[2] Kotler dan Keller, 2010 Manajemen Pemasaran, Jilid 2. Terj. Bob Sabran. Jakarta, Erlangga.

[3] Stanton, William J. 2003. Prinsip Pemasaran. Alih Bahasa oleh Sadu Sundaru. Jilid Satu. Edisi Kesepuluh. Jakarta : Erlangga

[4] Semi, Putri. 2014. "Pengaruh Promosi Terhadap Peningkatan Jumlah Siswa Pada Lembaga Pendidikan dan Pelatihan LPS Komputer Kec. Air Joman Kabupaten Asahan". Sekolah Tinggi Ilmu Ekonomi Muhammadiyah Asahan

[5] Husni Faqih, "Implementasi Dss Dengan Metode Saw Untuk Menentukan Prioritas Pekerjaan Operasi Dan Pemeliharaan Sistem Irigasi Dpu Kabupaten Tegal," Bianglala Informatika, vol. II, no. 1, Maret 2014.

[6] Rangkuti, Freddy. 2009. Strategi Promosi Yang Kreatif Dan Analisis Kasus Integrated Marketing Communication. Jakarta : Gramedia.

[7] Handayani, Dian Novita., et.al. 2014. Sistem Pendukung Keputusan Untuk Pemilihan Jurusan Menggunakan Fuzzy Multiple Atribute Decision Making dengan Metode Simple Additive Weighting Studi Kasus Pada.

[8] Marpaung, Nasrun. "Penerapan
Metode Simple Additive Weighting Pada Sistem Pendukung Keputusan Untuk Menentukan Kenaikan Gaji Karyawan." JURTEKSI 4.2 (2018): 171-178.

[9] Marpaung, Nasrun. "Penerapan Metode Simple Additive Weighting Pada Sistem Pendukung Keputusan Untuk Menentukan Kenaikan Gaji Karyawan. " JURTEKSI 4.2 (2018): 171-178. 